\title{
TREE DAMAGE AND MISTLETOE IMPACT ON URBAN GREEN AREAS
}

\author{
Dionicio Alvarado-Rosales ${ }^{2} \odot$ and Luz de Lourdes Saavedra-Romero $2^{*} \cdot($
}

\author{
${ }^{1}$ Received on 06.07.2020 accepted for publication on 31.01.2021. \\ 2 Colegio de Postgraduados, Programa de Fitosanidad-Fitopatología, Texcoco, México. E-mail: <saavedra.luz@colpos.mx> and \\ $<$ dionicio@colpos.mx>. \\ *Corresponding author.
}

\begin{abstract}
Green areas in cities provide several benefits to people, however, several biotic and abiotic agents affects the tree's health. The main goals of this research were to identify tree damages and to assess the impact of mistletoe on dendrometric variables and the crown condition. Four thousand, seven hundred seventyfive trees were evaluated in 16 green areas of eight Mayoralties in Mexico City; each tree was labeled, and total tree height (Th), diameter at breast height (DBH), damage agents (up to three types), and the crown variables: Live crown ratio (Lcr), Crown dieback (Cdie), Mistletoe severity (Ms) and Crown position (Cpo) were recorded. Of the assessed trees, 3318 presented damage. For the type of damage 1, the mistletoes Cladocolea and Struthanthus showed an average incidence of $42 \%$. For type 2, 20 agents and type 3, 11 were identified. Mechanical wounds, sucking insects, vandalism, and cankers were the most common damages. Based on the Principal Component Analysis (PCA), trees of all diameters and heights were infected, however, Struthanthus was associated with taller and larger diameter trees. Lcr was lower, and Cdie and Ms were higher in infected trees. About Cpo, dominant and codominant trees showed the highest levels of severity by mistletoe. The most affected tree genera were Ulmus and Populus (low Lcr and high Cdie and Ms). Cladocolea was found toward southern Mayoralties, and Struthanthus at the north. It is recommended to assess at least two types of damage on each tree, as this will provide a more complete picture of its health. This is the first study in Mexico on the impact of mistletoe on tree crown variables
\end{abstract}

Keywords: Cladocolea; Struthanthus; Crown condition.

\section{DANOS NAS ARVORES E O IMPACTO DE ERVAS-DE-PASSARINHO NAS AREAS VERDES URBANAS}

\begin{abstract}
RESUMO - As áreas verdes nas cidades oferecem muitos beneficios para as pessoas, no entanto, vários agentes bióticos e abióticos afetam a saúde das árvores. Os principais objetivos desta pesquisa foram identificar os danos em árvores e avaliar o impacto de ervas-de-passarinho nas variáveis dendrométricas e condição de copa. Quatro mil setecentos e setenta e cinco árvores foram avaliadas em 16 áreas verdes de oito prefeituras na Cidade do México. Cada árvore foi identificada, e a altura total da árvore (Th), o diâmetro na altura do peito (DBH), os agentes de danos (até três tipos) e as variáveis de copa: proporção da copa viva (Lcr), morte da copa (Cdie), severidade da erva-de-passarinho (Ms) e a posição na copa (Cpo) foram registradas. Das árvores avaliadas, 3318 apresentaram danos. Para o tipo de dano 1, as ervas-de-passarinho Cladocolea e Struthanthus apresentaram uma incidencia média de 42\%. Para o tipo 2, 20 agentes, e para o tipo 3, 11 foram identificados. Feridas mecânicas, insetos sugadores, vandalismo e cânceres foram os danos mais comuns. Com base na Análise de Componentes Principais (PCA), árvores de todos os diâmetros e alturas foram infectadas, entretanto, Struthanthus foi associado a árvores mais altas e diametros maiores. Lcr foi menor, e Cdie e Ms foram maiores nas árvores infectadas. Sobre Cpo, as árvores dominantes e codominantes apresentaram os maiores níveis de severidade por erva-de-passarinho. Os gêneros de árvores mais afetados foram Ulmus $e$ Populus (baixo Lcr e alto Cdie e Ms). Cladocolea foi encontrada predominantemente nas prefeituras do sul e Struthanthus ao norte. Recomenda-se avaliar pelo menos dois tipos de dano a cada árvore, pois isso fornecerá um quadro mais completo de sua saúde. Este é o primeiro estudo no México sobre o impacto de ervas-depassarinho nas variáveis de copa das árvores.
\end{abstract}

Palavras-Chave: Cladocolea; Struthanthus; Condição da copa.

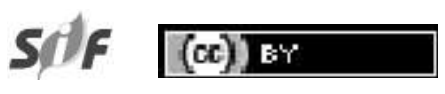

Revista Árvore 2021;45:e4530 http://dx.doi.org/10.1590/1806-908820210000030 


\section{INTRODUCTION}

Trees provide to the almost 10 million inhabitants of Mexico City (CDMX), shadow, removal of atmospheric pollutants, reduction in noise levels, and beauty of the environment with its shapes, textures and colors. Also, improve physical and psychological health, and increase in property value (ISA, 2011); the benefits trees provide are greater than that of other plant species (Johnston, 2010). Preserving and increasing the urban green spaces are goals of the World Health Organization (12 $\mathrm{m}^{2}$ of green area per capita) (MezaAguilar, 2015), unfortunately, reaching this figure is unlikely, given the current conditions prevailing in the city, where conservation and maintenance of green areas have not been efficient due to the lack of personnel and the small budget allocated to their care. There are numerous cases of stress and death of urban trees by different damaging agents, but few have been documented in Mexico (Saavedra-Romero et al., 2019; Alvarado-Rosales et al., 2007). Nowadays, green areas of CDMX faces a serious problem with the loss of a significant number of trees, as well as its accelerated loss of vigor, which makes them more susceptible to the attack of pests and diseases, among which are mistletoes that may weaken and kill their hosts (Alvarado-Rosales and Saavedra-Romero, 2005). There are reports on mistletoe incidence of 83\% (Sandoval-Cruz and Gutiérrez-Garduño, 2006), and until $95 \%$ of the existing tree species infected (Meza-Aguilar, 2015; PAOT, 2010). However, few studies are covering large urban areas that focus on mistletoe identification and damage assessment, with one exception (Arriola-Padilla et al., 2013), most have been local (Alvarado-Rosales and Saavedra-Romero, 2005; Pérez-Olvera et al., 2006; Díaz-Limón et al., 2016), and unfortunately, the exact distribution and impact of the mistletoe are unknown, a situation that does not allow large-scale management.

Mistletoe increases transpiration rates, selective uptake of xylem solutes that promote mineral enrichment of the mistletoe and shortage in the host (Tennakoon and Pate, 1996), and high absorption rates of heterotrophic carbon that can oscillate between 5 and 70\% (Bell and Adams, 2011); over time, the mistletoe appropriates the space previously occupied by the foliage of the tree, and the site of infection becomes a weak structure that increases host susceptibility to other pathogens such as fungi, bacteria, etc. (Boussinm et al., 2004). Other effects in the host are dieback, branches girdling, slow growth in diameter and height, water stress, reduction of flowering, fruiting, "broom effect" and finally decline and death of the tree (Coder, 2004).

The Program of Forest Inventory and Analysis of the United States of America (FIA), measures a set of health indicators to know the current status and health trends of their forested areas. The program considers dasometric measurements such as total tree height, diameter at breast height, crown condition, tree damage and others (Stolte et al., 2002). These indicators have been applied in the urban scenario of different green areas of the world (Cumming et al., 2001) and, recently, in Mexico, in Alameda north, east and south (Zaragoza-Hernández et al., 2014), and in the urban park San Juan de Aragon (SaavedraRomero et al., 2016; 2019; 2020). The effect of mistletoe on crown dimensions, shape and appearance of the trees have been little studied, although there is evidence that they affect the architecture of the crown and, consequently, canopy structure (Bell and Adams, 2011; Godfree et al., 2002). Due to the lack of studies on the current health condition of the urban green areas, the main goals of this research was to identify the different types of tree damage and to assess the impact of mistletoe on dasometric and crown condition variables in tree genera and green areas of Mexico City.

\section{MATERIALS AND METHODS}

\subsection{Study Area}

This work was carried out in 16 green areas of eight Mayoralties of Mexico City (CDMX): Azcapotzalco (ALN), Coyoacan (ALS, HUESO, CTMC, SDCH), Cuauhtemoc (ALC, REFN, REFC), Gustavo A. Madero (EMOL, GAMV), Miguel Hidalgo (REFS, CHAP), Iztacalco (IZT), Tlalpan (TECM) and Venustiano Carranza (ALO, VC). These areas were chosen due to the high incidence of mistletoe, according to reports from the authorities responsible for urban green areas in Mexico City. The total green area evaluated was five hectares.

\subsection{Data collection}

In each green area, following a zig-zag pattern, dasometric and crown condition variables were

Revista Árvore 2021;45:e4530 
recorded for each tree. The Total height (Th) was obtained using a Haga gun and diameter at breast height $(\mathrm{DBH})$ was measured with a diametric tape. Tree damage and crown condition variables were recorded based on FIA (Forest Inventory and Analysis Program of the United States of America) protocols (USDA, 2005).

\subsection{Tree damage}

The tree damage indicator protocol proposed by the Forest Inventory and Analysis Program (Conkling, Coulston, and Ambrose, 2005) was implemented. Up to three types of damage were recorded per tree (Types 1, 2 and 3), in four different locations (root, stem, branches and foliage). Type of damage 1 corresponded only to the presence of mistletoe, for which the severity level in percentage was determined. Type of damage 2 and 3 represented other agents in the same tree, in case they were present. The causes of damage were not collected. The information was recorded in a modified special format used by the FIA (Alvarado-Rosales and Saavedra-Romero, 2005). To collect the information, a field guide was designed with codes per agent of damage, in which a total of 41 damage agents were included, divided into five general categories (abiotic, anthropogenic, diseases, insects and wildlife). This was elaborated based on the experience of the authors, and previous studies (Saavedra-Romero et al., 2019; Alvarado-Rosales et al., 2007).

\subsection{Crown condition variables}

The following variables were recorded in every tree: (1) Crown position (CPo) - relative position of the canopy of a tree in relation to the upper layer of the canopy and codes 1 to 3 were assigned to represent dominant, codominant and suppressed trees, respectively; (2) Live crown ratio (Lcr) - relation between crown length and total tree height; (3) Crown dieback (Cdie) - recent mortality of branches with fine twigs, which starts at the terminal portion of a branch and progress inward. The Lcr and Cdie were measured in 5\% classes (Schomaker et al., 2007).

\subsection{Statistics Analysis}

To determine the impact of mistletoe infection on different tree genera and green areas, six dasometric and crown condition variables were analyzed using a Principal Component Analysis (PCA). This multivariate method was used to analyze a data matrix of 4424 rows and six columns (variables): Total height (Th), Diameter at breast height (DBH), Live crown ratio (Lcr), Crown position (Cpo), Mistletoe severity (Ms) and Crown dieback (Cdie). The analysis of the database was carried out using InfoStat software version 2017 (Di Rienzo et al., 2017).

One important step to employ PCA is the previous transformation of the original data. All variables were standardized, that is, with mean $=0$ and standard deviation $=1$. Based on the objectives of the present study, the classification criteria used in the analysis were: (a) Mistletoe genera (Cladocolea, Struthanthus, and trees apparently healthy); (b) Tree genera and (c) Green areas. For this study, the first two principal components were selected according to Kaiser's criterion, i.e. components with eigenvalues $\geq 1$ were considered (Stojnic et al., 2019). Also, their respective Biplots were elaborated, Pearson's correlation coefficients with the original variables and squared cosines were obtained to verify the association of variables.

\section{RESULTS}

Four thousand, seven hundred seventy-five trees were evaluated from 16 green areas in México City. Nineteen genera were identified and their frequencies were: Fraxinus (31.97\%), Populus (16.71\%), Ulmus (7.64\%), Eucalyptus (7.32\%), Ligustrum (6.78\%), Casuarina (6.05\%), Cupressus (5.85\%), Jacaranda (5.52\%), Ficus (2.63\%) and Acacia (2.09\%). Other genera such as Salix, Pinus, Acer, Grevillea, Alnus, Liquidambar, Schinus and Erythrina had frequencies less than 2\%. Total trees were grouped into 13 diameter categories. Classes 12.5 to $17.4 \mathrm{~cm}$ (18.22\%) and $17.5-22.4 \mathrm{~cm}(19.28 \%)$ were the most frequent. In terms of height, the 7.5 to $15 \mathrm{~m}(58.11 \%)$ class was the most numerous.

\subsection{Tree Damage (Type 1, 2 and 3)}

Of the 4775 assessed trees, 3318 were recorded with damage; in the rest 1475 no damages were detected. For the type of damage 1, two mistletoe species were found, Struthanthus and Cladocolea with an average incidence of 42\% (2005 trees). Struthanthus was the most frequent because it was

Revista Árvore 2021;45:e4530 
found on 1238 trees (incidence of $25.9 \%$ ) and 767 trees $(16.1 \%)$ infected by Cladocolea.

For the type of damage 2, 20 agents were recorded affecting at least 3318 trees, the most frequent were wounds, sucking insects, vandalism and topping, and the most affected organs were trunk with $57 \%$, foliage $28 \%$, branches $8 \%$ and roots $7 \%$.

Finally, for the type of damage 3, 11 damage agents were identified affecting 1329 trees and, again, wounds and sucking insects showed the highest frequencies. Regarding the affected organs, foliage was the most common with $43 \%$, trunk $41 \%$, branches $11 \%$, and roots $5 \%$. In Figure 1, damage agents affecting more than 20 trees are shown.

Based on the analysis criteria, two main principal components (PC) were obtained for tree genera infected by Cladocolea, Struthanthus, and trees without mistletoe (apparently healthy), respectively (Tables 1A). The same for green areas (Table 1B).

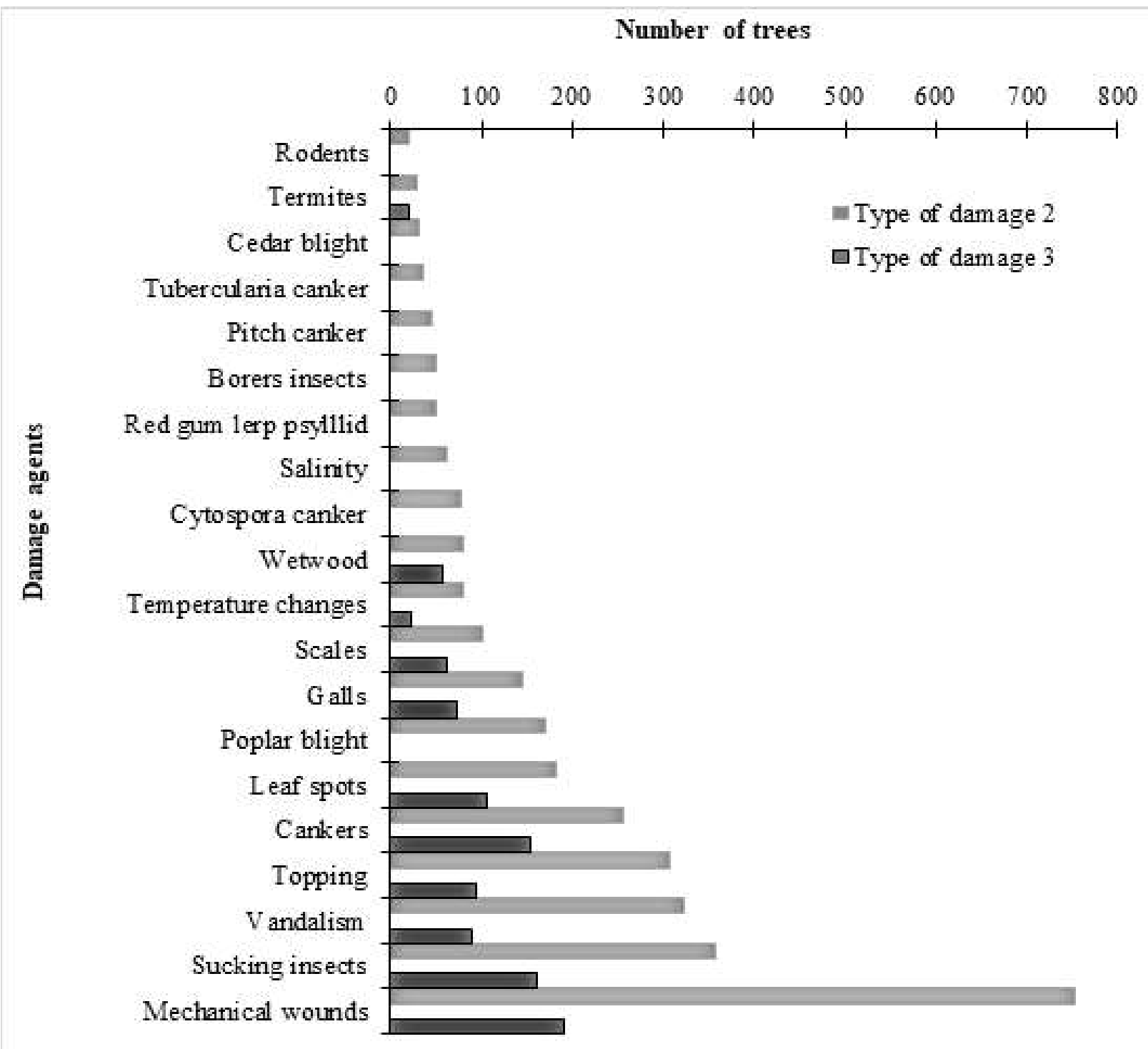

Figure 1 - Frequency of types of damage identified in the green areas of Mexico City under the criterion of $\mathrm{n}>20$ affected trees.

Figura 1 - Freqüência dos tipos de danos identificados nas áreas verdes da Cidade do México sob o critério de n>20 árvores afetadas.

Revista Árvore 2021;45:e4530 
Table 1 - Eigenvalues and percentage of variance explained for the main components obtained, using tree genera (A) and green areas (B) as classification criteria.

Tabela 1 - Autovalores e porcentagem de variância para os components principais, usando gêneros de árvore (A) e áreas verdes (B) como critérios de classificação.

\begin{tabular}{|c|c|c|c|c|c|c|c|c|c|}
\hline & & & & A. & Tree genera & & & & \\
\hline & \multicolumn{3}{|c|}{ Cladocolea } & \multicolumn{3}{|c|}{ Struthanthus } & \multicolumn{3}{|c|}{ Apparently healthy } \\
\hline & $\overline{\text { Eigenvalue }}$ & $\begin{array}{c}\text { Variability } \\
(\%)\end{array}$ & $\begin{array}{c}\text { Cumulative } \\
(\%)\end{array}$ & $\overline{\text { Eigenvalue }}$ & $\begin{array}{c}\text { Variability } \\
(\%)\end{array}$ & $\begin{array}{c}\text { Cumulative } \\
(\%)\end{array}$ & $\overline{\text { Eigenvalue }}$ & $\begin{array}{c}\text { Variability } \\
(\%)\end{array}$ & $\begin{array}{r}\text { Cumulative } \\
(\%)\end{array}$ \\
\hline$\overline{\text { PC } 1}$ & 3.09 & 51.5 & 51.5 & 2.66 & 44.3 & 44.3 & 2.55 & 42.5 & $\overline{42.5}$ \\
\hline PC 2 & 1.74 & 29 & 80.5 & 2.41 & 40.1 & 84.4 & 1.69 & 28.2 & 71.7 \\
\hline \multirow[t]{2}{*}{ PC 3} & 0.79 & 13 & 94 & 0.66 & 11 & 96 & 0.90 & 15 & 86 \\
\hline & & & & B. & Green areas & & & & \\
\hline PC 1 & 3.88 & 65 & 65 & 3.42 & 57 & 57 & 2.33 & 39 & 39 \\
\hline PC 2 & 1.59 & 26 & 91 & 1.05 & 17 & 74 & 1.96 & 33 & 72 \\
\hline PC 3 & 0.42 & 07 & 0.98 & 0.7 & 12 & 86 & 0.84 & 14 & 85 \\
\hline
\end{tabular}

Note: Only principal components with eigenvalues $\geq 1$ were considered according to Kaiser's criterion.

Nota: Apenas componentes principais com autovalores $\geq 1$ foram considerados de acordo com o critério de Kaiser

Only components with eigenvalues $\geq 1$ were selected, which presented the highest percentage of explained variance with $80.5,84.4 \%$ and $71.7 \%$ in the case of tree genera (Table 1A) and 91,74 y $72 \%$ for green areas (Table 1B).

The Pearson's correlation coefficients with the original variables are shown in Tables $2 \mathrm{AB}$. Only variables with coefficients $\geq 0.5$ were selected, which was also ratified with the squared cosines higher than 0.5 (values not included). In this sense, the most outstanding contribution to the first PC (case Cladocolea) (Table 2A), was obtained from $\mathrm{DBH}$,
Th, and Cdie all of them with positive correlations, and $\mathrm{Cpo}$ with negative correlations. For the $\mathrm{PC} 2$, the best correlations were for Ms and Lcr, both negatives. Meanwhile, for Struthanthus the most outstanding contribution to the PC1 was obtained from Th, Ms and Cdie, all of them with positive, and Cpo and Lcr with negative correlations. For PC2, the best positive correlation was for DBH. Finally, for the trees apparently healthy, a PC3 was obtained associated with Ms.

Regarding to green area, the most notable contribution to the $\mathrm{PC} 1$ was obtained from $\mathrm{DBH}$,

Table 2 - Pearson's correlation coefficients between original variables and their principal components using tree genera (A) and green areas (B) as classification criteria.

Tabela 2 - Coeficientes de correlação de Pearson entre as variáveis originais e seus componentes principais usando gêneros de árvores (A) é áreas verdes (B) como critérios de classificação.

\begin{tabular}{|c|c|c|c|c|c|c|c|c|c|}
\hline \multirow[b]{3}{*}{ Variable } & \multirow{2}{*}{\multicolumn{3}{|c|}{ Cladocolea }} & \multirow{2}{*}{\multicolumn{3}{|c|}{$\begin{array}{l}\text { Tree genera } \\
\text { Struthanthus } \\
\end{array}$}} & & & \\
\hline & & & & & & & \multicolumn{3}{|c|}{ Apparently healthy } \\
\hline & PC 1 & PC 2 & PC 3 & PC 1 & PC 2 & PC 3 & PC 1 & PC 2 & PC 3 \\
\hline$\overline{\mathrm{DBH}}$ & 0.8 & 0.12 & 0.53 & 0.5 & -0.72 & -0.41 & 0.68 & -0.4 & -0.33 \\
\hline $\mathrm{Th}$ & 0.97 & 0.02 & 0.21 & -0.07 & -0.86 & 0.49 & 0.93 & -0.22 & 0.1 \\
\hline Ms & 0.47 & -0.68 & -0.49 & -0.86 & -0.28 & -0.41 & 0.34 & -0.39 & 0.85 \\
\hline Cpo & -0.74 & -0.48 & 0.35 & -0.38 & 0.88 & -0.08 & -0.82 & 0.15 & 0.21 \\
\hline Ler & 0.37 & 0.83 & -0.30 & 0.93 & -0.05 & -0.26 & 0.39 & 0.88 & 0.08 \\
\hline \multirow[t]{2}{*}{ Cdie } & 0.78 & -0.6 & -0.03 & -0.81 & -0.54 & -0.12 & -0.52 & -0.74 & -0.13 \\
\hline & & & & B. & Green ar & & & & \\
\hline Variable & PC 1 & $\mathrm{PC} 2$ & PC3 & PC 1 & PC 2 & PC 3 & PC 1 & PC 2 & $\mathrm{PC} 3$ \\
\hline$\overline{\mathrm{DBH}}$ & 0.95 & 0.31 & 0.01 & 0.36 & 0.79 & 0.49 & 0.52 & -0.71 & $\overline{0.20}$ \\
\hline Th & 0.80 & -0.32 & 0.48 & 0.81 & 0.24 & -0.26 & 0.89 & 0.19 & -0.03 \\
\hline Ms & 0.22 & 0.96 & 0.12 & 0.85 & -0.09 & -0.03 & 0.12 & -0.54 & 0.83 \\
\hline Cpo & -0.94 & -0.32 & 0.05 & -0.82 & -0.20 & 0.47 & -0.56 & -0.69 & 0.30 \\
\hline Lcr & 0.89 & 0.11 & -0.42 & -0.69 & 0.50 & -0.34 & -0.37 & 0.81 & -0.11 \\
\hline Cdie & -0.78 & 0.59 & 0.01 & 0.87 & -0.26 & 0.24 & 0.90 & 0.05 & -0.05 \\
\hline
\end{tabular}


Th and Lcr all of them with positive, and Cpo and Cdie with negative correlations. For PC2, the best positive correlations were for Ms. For Struthanthus, the PC1 was conformed by Th, Ms and Cdie (positive correlations), and Cpo and Lcr (negative correlation), meanwhile, for $\mathrm{PC} 2$, the $\mathrm{DBH}$ with positive correlation. On the other hand, the trees apparently healthy showed three components (Table 2B).

\subsection{Mistletoe impact on dasometric and crown condition variables}

Two sets of variables were obtained, both with positive correlations. The first, formed by $\mathrm{DBH}$ and $\mathrm{Th}$, and the second, by Cdie and Ms. On the other hand, Cpo, DBH and Th presented a negative correlation. Struthanthus was associated with taller trees and higher DBH (Figure 2).

Regarding crown condition variables, the Lcr was different between infected and non infected trees. For the first one, Lcr decreased (Figure 2), meanwhile, trees apparently healthy were associated with higher Lcr, and low Ms and Cdie (negative correlation). The crown position was negatively correlated with Cdie and Ms, that is, dominant and codominant trees had higher values of these variables. The same association was held for Th. On trees infected by Struthanthus, the live crown ratio (Lcr) was lower than that of Cladocolea. Trees infected by Cladocolea had the highest values for Cdie and Ms. Few trees without apparent infection showed Cdie. Regarding the

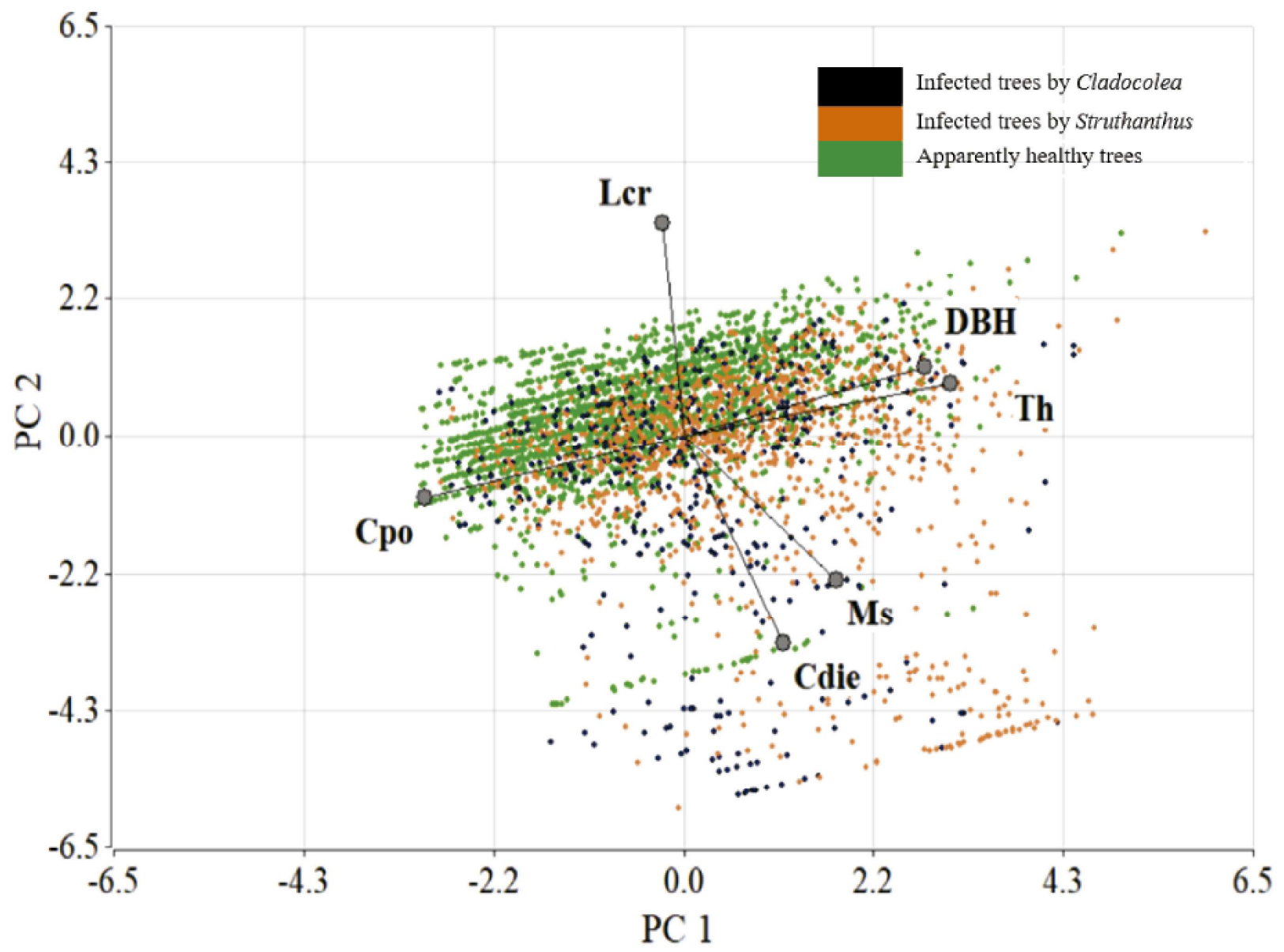

Figure 2 - 2D Biplot of the variables associated with infected trees, and apparently healthy. Lcr: Live Crown ratio; Cdie: Crown dieback; Ms: Mistletoe severity, DBH: Diameter at breast height; Th: Total height and Cpo: Crown position.

Figura 2-2D Biplot das variáveis associadas a árvores infectadas e árvores aparentemente saudável. Lcr: proporção da copa viva; Cdie: morte da copa; Ms: severidade da erva-de-passarinho; DBH: diâmetro na altura do peito; Th: altura total, e Cpo: Posição da copa.

Revista Árvore 2021;45:e4530 

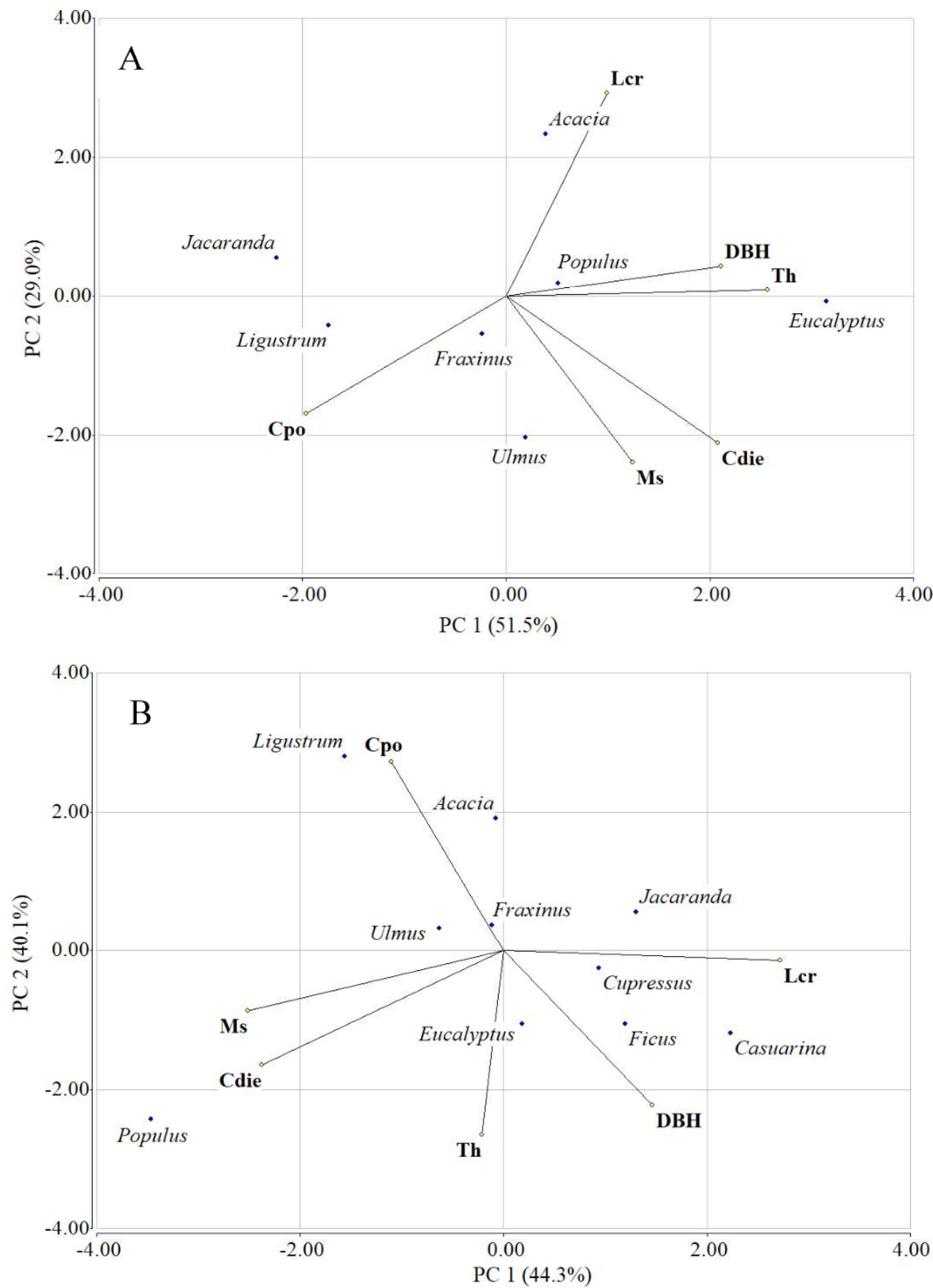

Figure 3-2D Biplot of the variables associated with the first two components of the PCA of the relationship between genera of mistletoe and 10 tree genera. A. Cladocolea. B. Struthanthus. Lcr: Live Crown ratio; Cdie: Crown dieback; Ms: Mistletoe severity, DBH: Diameter at breast height; Th: Total height and Cpo: Crown position.

Figura 3 - 2D Biplot das variáveis associadas aos dois primeiros componentes do PCA para o relação entre gêneros de erva-de-passarinho e 10 gêneros de árvores. A. Erva-de-passarinho Cladocolea. B. Erva-de-passarinho Struthanthus. Lcr: proporção da copa viva; Cdie: morte da copa; Ms: severidade da erva-de passarinho; DBH: diametro na altura do peito; Th: altura total, e Cpo: Posição da copa. 
sociological position (Cpo), the dominant and codominant trees presented high severity for both mistletoes (Figure 2).

\subsection{Mistletoe impact on tree genera and green areas}

Ten tree genera were infected by mistletoe (tree genera with frequencies less than $2 \%$ are not shown). Dissimilarities were found in the crown condition variables by tree genera infected by Cladocolea (Figure 3A). Ligustrum, Fraxinus and Ulmus exhibited the lowest values of Lcr, meanwhile Acacia presented the highest Lcr and the lowest values for Ms and Cdie. Finally, the Ms was higher in Ulmus.

For trees infected by Struthanthus (Figure 3B), Populus showed the lowest Lcr and the highest Ms and Cdie. The Cdie was light in Jacaranda, Cupressus, Ficus and Casuarina. The Ms was lowest for Cupressus, Fraxinus, Ficus and Casuarina. The biplot for healthy trees was not included.

In the case of green areas, two sets of variables were obtained for Cladocolea, the first, consisting of $\mathrm{DBH}$, Th and Lcr with positive correlations, where the RFN and RFC areas were located with the largest trees in height, diameter and Lcr, and high Cdie and Ms. The second set of variables consisted of Cdie and Cpo (negative correlation). The green areas CTM, TCM and REFS with dominant trees presented the highest Cdie, the same happened for ALS and HUESO. For Struthanthus, two sets of variables were also obtained, the first, consisting of Th, Ms and Cdie with positive correlations, and the second, by Cpo and Lcr (negative correlations). In RFN the tallest trees were located, with the highest Ms and Cdie, and the lowest LCR. The dominant and codominant trees of RFC, RFS, EMOL, CHAP, GAMV and CTMC presented high Cdie and Ms. In general terms, it was possible to observe that the spatial distribution of the two genera of mistletoe was different, Cladocolea was found in the southern Mayoralties (Coyoacan and Tlalpan), and Struthanthus at north (Azcapotzalco and Cuauhtemoc Mayoralties).

\section{DISCUSSION}

Fraxinus and Populus are two genera that, for various reasons, dominates in the CDMX (Chacalo et al., 1994), and concerning the first one, it is in the category of urban monument, so its ecological value is greater (Meza-Aguilar, 2015). In this sense, their current condition assessment is a priority.

In general, trees evaluated presented mediumto-low diameter and height dimensions, possibly due to their recent planting, or to the lack of necessary nutritional resources that did not allow them to achieve their maximum growth potential.

The presence of Cladocolea and Struthanthus as the most frequent genera in this study, agree with several other reports (Alvarado-Rosales and SaavedraRomero, 2005; Pérez-Olvera et al., 2006; Díaz-Limón et al., 2016; Valencia, 2009), but contrast with others where they found $4.2 \%$ incidence for Cladocolea loniceroides (Van Tieghem) Kuijt, Phoradendron velutinum (DC.) Nutt. and Struthanthus interruptus (Kunth) G. Don. in 16 Mayoralties of CDMX ( $n=2653$ trees) (Arriola-Padilla et al., 2013). However, in another survey, they report $83 \%$ incidence in 10 Mayoralties of the CDMX and three infection levels, $29 \%$ light, 25\% medium and 29\% severe, the healthy trees occupied 17\% (Sandoval-Cruz and GutiérrezGarduño, 2006). In the presen study, the incidence was $42 \%$ for both mistletoes in eight Mayoralties of Mexico City, contrasting with the results of previously mentioned studies.

Previous studies report that wounds, toppings and vandalism are the most frequent damaging agents that affect the health of trees in the green areas of CDMX (Sandoval-Cruz and Gutiérrez-Garduño, 2006; PérezOlvera et al., 2006). In addition to this, urban trees are facing an increasingly hostile environment where soil compaction, lack of irrigation and inappropriate management measures contribute to exacerbate their condition (Meza-Aguilar, 2015). In Hong Kong, in 10 different arboreal habitats (public-private parks, etc.), 30 defects-disorders were identified in 352 evaluated trees, wounds, cavities and wood decay were the most abundant, among other structural defects (Jim and Zang, 2013). The identification of damages in urban green areas, will allow to prioritize areas, allocate resources and train the responsible personnel to carry out efficient management activities. It is important to note that because the urban trees are exposed to strong anthropogenic pressure, a high proportion of the damage was anthropic, so it is important to create ecological awareness among users, including the responsible authorities, to preserve this scarce resource.

Revista Árvore 2021;45:e4530 


\subsection{Impact of mistletoe in tree genera and green areas}

Based on the Principal Component Analysis (PCA), six study variables (dasometric and crown condition) were analyzed to determine the impact of the severity of mistletoe infection in tree genera and green areas in Mexico City. The main components obtained were well represented, explaining a percentage of variance higher than $70 \%$ in all cases (Table $1 \mathrm{AB}$ ), as well as acceptable correlation coefficients higher than 0.65 (Table 2AB).

Few studies report a relationship between dasometric variables and levels of mistletoe infection, among them those by Downey (2004) and Kołodziedjed et al. (2013). According to the results of the present study, the intensity of mistletoe infection was affected by the individual characteristics of the tree, such as height and diameter. It was observed that Struthanthus and Cladocolea to a lesser degree are associated with taller trees and greater diameters (Figures 2 and 3). Also, other surveys report that the initial infection by mistletoe occurs in many cases in large or over-mature trees, that birds like for perch and shelter (Zuber, 2004; Norton and Reid, 1997); as a reward, the mistletoe offers its colorful seeds, thereby establishing a strong mutualistic relationship useful for the dissemination of the parasite (Kolodziejek et al., 2012; Aukema, 2003). According to Clark-Tapia et al. (2011), when the height and diameter of trees increase, the mistletoe severity by Phoradendron bolleanum in Juniperus deppeana (Steud.) increases. The same relationship is confirmed between Acacia robusta Burch. and Phoradendron californicum Nutt. (Ndagurwa et al., 2012), while the abundance of the mistletoe Phragmanthera dschallensis (Engl.) MG Gilbert, depends on the size and age of the host tree and, ultimately, on the perching preferences of the three species of birds involved in the dispersal of their seeds (Roxburgh and Nicolson, 2008). These studies support too our results, that is, there is a positive correlation between tree height and diameter, with the mistletoe severity.

Notwithstanding that, crown variables are used to monitor tree health, our country does not count on standards for their tree species and geographic conditions, due to this, the studies of Randolph (2004) and Metzger and Oren (2001), were taken as a reference.
The authors conclude that trees with Lcr $>30 \%$ and Cdie $<5 \%$ are considered healthy. In this sense, and for the data analyzed in this study, the crown live ratio, are higher especially in trees apparently healthy. Besides this, high Lcr values are also indicative of healthy and fast growing trees (Schomaker et al., 2007). Based on the authors previously mentioned, in the present study, trees with low Lcr and high Cdie, in addition to high levels of mistletoe infection, were rated as unhealthy. These results are supported by the studies carried out by Godfree et al. (2002) with dwarf mistletoe that concludes that Lcr is lower when mistletoe infection develops in the upper part of the crowns. On the other hand, trees with low Cdie are considered healthy because they have a greater potential for carbon fixation and storing nutrients.

About the relationship found between height and sociological position of the trees versus the level of mistletoe severity, dominant and codominant trees showed higher values. A study that supports these findings was made by artificially inoculating seeds of Psittacanthus schiedeanus (Cham. \& Schiecht) Blume ex. Schultes, on five hosts, showing that the established seedlings had a higher survival rate in the trees where the canopy was more open (Buen and Ornelas, 2002), under these conditions, the parasite has a strategic position at the upper part of the canopy where it receives a greater amount of photosynthetically active radiation that will allow it to develop (Těšitel et al., 2010).

One of the most recent studies reports 17 hosts infected by mistletoe (Arriola-Padilla et al., 2013). In this survey, some host "specificity" was observed, Struthanthus was associated with Ficus, Casuarina, Cupressus, Ligustrum, Jacaranda and Populus, meanwhile Cladocolea was not present in the first three hosts (Figure3AB). These results agree with Valencia (2009). It was possible to differentiate also a regional distribution for each mistletoe, Cladocolea towards the south of Mexico City's Mayoralties (Coyoacan and Tlalpan), and Struthanthus with elevated reproductive success in the north green areas (Azcapotzalco and Cuauhtemoc). The reasons to explain why Cladocolea is concentrated towards south Mayoralties, and Struthanthus in the north are unknown, but environmental conditions could be the main reason. However, over time, the levels of infection have increased, and an overlap in distribution and host

Revista Árvore 2021;45:e4530 
tree species has also been observed. It was recorded tree species parasitized by both mistletoes, even in the same tree. Fewer tree species were assessed without apparent infection (Valencia, 2009).

In the future, this kind of results can help us in the planning and decision-making for the management of these parasitic plants.

\section{CONCLUSIONS}

For the type of damage 1, the mistletoes Cladocolea and Struthanthus showed an average incidence of $42 \%$, for the type of damage 2, 20 agents were identified and for type 3, 11. Mechanical wounds, sucking insects, vandalism, cankers, and topping, were the most frequent. The assessment of two types of damage at least is highly recommended because it provides a better picture of tree health. Struthanthus was associated with trees of greater size. In severely infected trees, the Live crown ratio was lower and Crown dieback was higher, particularly on Ulmus and Populus. Dominant and codominant trees showed the highest levels of infection. In this study, the use of component analysis was a very useful tool to determine the impact of mistletoe.

\section{AUTHOR CONTRIBUTIONS}

D.A.R., and L.L.S.R. conceived the ideas and designed the methodology, collected the field data, performed the statistical analysis of the data and contributed to the writing.

\section{ACKNOWLEDGMENTS}

To Secretaria del Medio Ambiente of Mexico City for funding this study through the Project "Establishing the baseline for the management of trees infected by mistletoe". We also thank Dr.Cristian Nava-Díaz for the review and suggestions to this manuscript.

\section{REFERENCES}

Alvarado-Rosales D, Saavedra-Romero LL. El género Cladocolea (Loranthaceae) en México: muérdago verdadero o injerto. Revista Chapingo, Serie Ciencias Forestales y del Ambiente. 2005;11(1):5-9.

Alvarado-Rosales D, Saavedra-Romero LL, Fenn
M, Hernández-Tejeda T, Cibrián-Tovar D. Abiotic factors that causes stress and death. In: CibriánTovar D, Alvarado-Rosales D, García-Díaz SE, editors. Forest diseases in Mexico. Texcoco, México: Universidad Autónoma Chapingo; 2007. p. 11-41. ISBN 968-02-0340-9.

Arriola Padilla VJ, Velasco Bautista E, Hernández Tejeda T, González Hernández A, Romero Sánchez ME. Los muérdagos verdaderos del arbolado de la Ciudad de México. Revista Mexicana de Ciencias Forestales. 2013;4(19):34-45. doi: 10.29298/rmcf. v4i19.377.

Aukema JE. Vectors, viscin, and Viscaceae: mistletoes as parasites, mutualists, and resources. Frontiers in Ecology and the Environment. 2003;1(3):212-219. doi: 10.2307/3868066.

Bell TL, Adams MA. Attack on all fronts: functional relationships between aerial and root parasitic plants and their woody hosts and consequences for ecosystems. Tree Physiology. 2011;31:3-15. doi: 10.1093/treephys/tpq108.

Buen LL, Ornelas JF. Host of compatibility of the cloud forest mistletoe Psittacanthus schiedeanus (Loranthaceae) in Central Veracruz, Mexico. American Journal of Botany. 2002; 89(1):95-102. doi: 10.3732/ajb.89.1.95.

Boussinm IJ, Guinko S, Tuquet C, Sallé G. Mistletoes of the agroforestry parklands of Burkina Faso. Agroforestry Systems. 2004;60:39-49. doi: 10.1023/B:AGFO.0000009403.36419.20.

Cumming AB, Galvin MF, Rabaglia RJ, Cumming JR, Twardus DB. Forest health monitoring protocol applied to roadside trees in Maryland. Journal of Arboriculture. 2001;27(3):126-138.

Chacalo A, Aldama A, Grabinsky J. Street tree inventory in Mexico City. Journal of Arboriculture. 1994;24(4):222-226.

Clark-Tapia R, Torres-Bautista B, AlfonsoCorrado C, Valdez-Hernández JI, GonzálezAdame G, Bretado-Velázquez J, et al. Análisis de la abundancia e infección por muérdago en Sierra Fría, Aguascalientes, México. Madera y Bosques. 2011;17(2):19-33.

Coder KD. American mistletoes. Kissing under a

Revista Árvore 2021;45:e4530 
parasite. Arborist News. 2004;13(6):37-44.

Conkling BL, Coulston J.W, Ambrose MJ editors. Forest health monitoring 2001 National Technical Report. Asheville, NC: U.S. Department of Agriculture, Forest Service, Southern; 2005. doi: doi. org/10.2737/SRS-GTR-81

Díaz-Limón MP, Cano-Santana Z, Quejeiro-Bolaños ME. Mistletoe infection in an urban forest in Mexico City. Urban Forestry and Urban Greening. 2016;17:126-134. doi: 10.1016/j.ufug.2016.04.004.

Di Rienzo JA, Casanoves F, Balzarini MG, Tablada M, Robledo CW. Infostat. Versión 2017. Córdoba: Centro de transferencia infoStat, FCA da Universidad Nacional de Córdoba Argentina.

Downey PO. A regional examination of the mistletoe host species inventory. Cunninghamia. 2004;8:354361 .

Godfree RC, Tinnin RO, Forbes RB. The effects of dwarf mistletoe, witches' brooms, stand structure, and site characteristics on the crown architecture of lodgepole pine in Oregon. Canadian Journal of Forest Research. 2002;32:1360-1371.

International Society of Arboriculture - ISA. Benefits of trees. 2011. [cited 2019 February 20]. Third Edition. Available from: https://www. treesaregood.org/portals/0/docs/treecare/benefits trees.pdf

Jim CY, Zhang H. Defect-disorder and risk assessment of heritage trees in urban Hong Kong. Urban Forestry and Urban Greening. 2013;12(4):585-596. doi: 10.1016/j.ufug.2013.06.003

Johnston M. Trees in towns II and the contribution of arboriculture. Arboricultural Journal. 2010;33(1):2741. doi: $10.1080 / 03071375.2010 .9747590$

Kołodziejek J, Patykowski J, Kołodziejek R. Distribution, frequency and host patterns of European mistletoe (Viscum album subsp. album) in the major city of Lodz, Poland. Biologia 2013;68(1):55-64. doi: 10.2478/s11756-012-0128-4.

Metzger JM, Oren R. The effect of crown dimensions on transparency and the assessment of tree health. Ecological Applications. 2001;11(6):1634-1640.

Meza Aguilar MC. Los árboles de la Ciudad de México: guardianes de su imagen y calidad ambiental. Bitácora arquitectura. 2015;(31):96-103. doi: 10.22201/fa.14058901p.2015.31.56652

Ndagurwa HGT, Mundy J, Dube PS, Mlambo D. Patterns of mistletoe infection in four Acacia species in a semiarid southern Arican savanna. Journal of Tropical Ecology. 2012;28(5):523-526. doi: 10.1017/ S0266467412000387.

Norton DA, Reid N. Lessons in ecosystem management from management of threatened and pest Loranthaceous mistletoes in New Zeland and Australia. Conservation Biology. 1997;11: 759-769. doi: 10.1046/j.1523-1739.1997.95529.x.

Procuraduría Ambiental y del Ordenamiento Territorial - PAOT. Presente y futuro de las áreas verdes y del arbolado de la Ciudad de México. Medellín: Estudios y publicaciones; 2010.

Pérez Olvera CP, Ceja-Romero J, Vela-Ramírez G. Árboles y muérdagos: una relación que mata. Revista Contactos. 2006;59:28-34.

Randolph KC. An evaluation of change in tree crown characteristics to assess forest health in two Indiana State parks. Northern Journal of Applied Forestry. 2004;21(1):50-55. doi: 10.1093/njaf/21.1.50.

Roxburgh L, Nicolson SW. Differential dispersal and survival of an African mistletoe: does host size matter? Plant Ecology. 2008;195:21-31. doi: 10.1007/s11258-007-9295-8.

Saavedra-Romero LL, Alvarado-Rosales D, Martínez-Trinidad T, Hernández-de la Rosa P. Physical and chemical properties of the urban soil in the San Juan de Aragon Park, Mexico City Terra Latinoamericana. 2020;38(3):529-540. doi: 10.28940/terra.v38i3.644.

Saavedra-Romero LL, Alvarado-Rosales D, Martínez-Trinidad T, Hernández-de la Rosa $P$. Identification of defects and risks in trees of San Juan de Aragon Forest, Mexico City. Revista Chapingo Serie Ciencias Forestales y del Ambiente. 2019;25(1):31-47. doi: 10.5154/r. rchscfa.2018.06.049

\section{Revista Árvore 2021;45:e4530}


Saavedra-Romero LL, Alvarado-Rosales D, Hernández-de la Rosa P, Martínez-Trinidad T, MoraAguilera G, Villa-Castillo J. Condición de copa, indicador de salud en árboles urbanos del Bosque San Juan de Aragón, Ciudad de México. Madera y Bosques. 2016;22(2):13-25.

Sandoval-Cruz L, Gutiérrez-Garduño MV. Plantas parásitas del arbolado urbano. Arbórea 8, 2006;(1819):23-32.

Schomaker ME, Zarnoch SJ, Bechtold WA, Latelle DJ, Burkman WG, Cox SJ. Crown-condition classification: a guide to data collection and analysis. Asheville: U.S. Department of Agriculture, Forest Service, Southern Research Station; 2007.

Stolte K, Conkling B, Campbell S. Forest Health Indicators. Forest Inventory and Analysis Program. FS-746. Nort Caroline: United States Department of Agriculture. 2002.

Stojnic S, Branislav K, Marko K, Vastag E, Bojovic M, Stankovic-Nedic M, Orlovic S. The use of physiological, biochemical and morpho-anatomical traits in tree breeding for improved wáter-use efficiency of Quercus robur L. Forest systems. 2019;28(3). doi: 10.5424/fs. 2019283-15233.

Tennakoon KU, Pate JS. Effects of parasitism by a mistletoe on the structure and functioning of branches of its host. Plant, Cell and Environment. 1996;19(5):517-528. doi: 10.1111/j.1365-3040.1996. tb00385.x.

Těšitel J, Plavcová L, Cameron D. Interactions between hemiparasitic plants and their hosts. Plant Signaling and Behavior. 2010;5(9):1072-1076. doi: 10.4161/psb.5.9.12563.

United States Department of Agriculture - USDA. Crown: measurements and sampling. In: Forest Inventory and Analysis National core field guide: field data collection procedures for phase 3 plots. 2005. Version 3.0. Section 12. Avaible from: https:// www.fia.fs.fed.us/library/field-guides-methods-proc/ docs/2006/p3_3-0_sec12_10_2005.pdf

Valencia DM. El muérdago en la Ciudad de México. Arbolama. 2009;1(2):10-30.

Zaragoza-Hernández A, Cetina-Alcalá VM, López-López MA, Chacalo-Hilú A, De la Isla ML, González H. General health condition in forest species in three parks in Mexico City: Crown condition. Research Journal of Environmental Science. 2014;8(1):1-16. doi: 10.3923/rjes.2014.1.16.

Zuber D. Biological flora of Central Europe: Viscum abum L. Flora. 2004;199:188-203. doi: 10.1078/0367-2530-00147. 